\title{
A Novel Mesoporous Carbon as Potential Conductive Additive for a Li-Ion Battery Cathode
}

\author{
Victor Vélez, Betty López, Ruben Palacio $\$ and Ligia Sierra *(1) \\ Grupo Ciencia de los Materiales, Sede de Investigación Universitaria (SIU), Universidad de Antioquia, \\ Calle 62 No. 52-59, Lab 310, Medellín 05001, Colombia; victorvelez4901@hotmail.com (V.V.); \\ bettylope@gmail.com (B.L.); rubenpalacio@gmail.com (R.P.) \\ * Correspondence: ligia.sierra@gmail.com
}

Received: 23 October 2019; Accepted: 18 November 2019; Published: 3 December 2019

check for updates

\begin{abstract}
A new mesoporous carbon (MC) is obtained from pyrolysis of resorcinol/formaldehyde resin, polymerized in the presence of tetraethoxysilane and Pluronic F108, followed by pyrolysis at $800{ }^{\circ} \mathrm{C}$ and silica removal. The reaction mixture in a molar ratio of 1 F108/60resorcinol/292 formaldehyde $/ 16900 \mathrm{H}_{2} \mathrm{O} / 50$ tetraethoxysilane heated at $67^{\circ} \mathrm{C}$ produces $\mathrm{MC}$ nanoparticles $(200 \mathrm{~nm}$ average size) exhibiting 3D bimodal mesopores ( 3.9 and $8.2 \mathrm{~nm}$ ), $1198 \mathrm{~m}^{2} / \mathrm{g}$ surface area, $1.8 \mathrm{~cm}^{3} / \mathrm{g}$ pore volume, and important graphitic character for use as a conductive material. Composites $\mathrm{LiFePO}_{4} /$ carbon prepared with $\mathrm{MC}$ or commercial Super P, by the slurry method, were tested as coin Li-ion battery (LiB) cathodes. Super P (40 nm average particle size) exhibits better graphitic character, but lower porosity than MC. $\mathrm{LiFePO}_{4} / \mathrm{MC}$ shows better specific capacity $\left(161 \mathrm{mAhg}^{-1}\right)$ than $\mathrm{LiFePO}_{4} /$ Super P $\left(126 \mathrm{mAhg}^{-1}\right)$, with a retention capacity (RC) after cycling at $C / 10$ of $81 \%$. Both composites with MC and Super P show well-distributed particles. According to impedance analysis, MC mesoporosity improves the charge transfer kinetics (CTK) more than Super P, producing a cathode with higher efficiency, although lithium ions' diffusion decreases because larger MC particles form longer diffusion paths. Owing to the good specific capacity of the LiB cathode prepared with MC, research looking into improving its retention capacity should be a focus.
\end{abstract}

Keywords: mesoporous carbon; graphitic character; lithium ion battery; conductive additive; cathode

\section{Introduction}

The lithium insertion compounds, with an olivine structure, are considered as potential positive electrode materials of large-scale lithium-ion rechargeable batteries (LIBs) for electric vehicles because of their high operative voltage and energy density. Among the olivine compounds, $\mathrm{LiFePO}_{4}$ as a cathode material in lithium ion batteries is important because it exhibits low toxicity and is obtained at a relatively low cost. Additionally, it has a high lithium intercalation voltage of $3.4 \mathrm{~V}$, which is compatible with most existing organic electrolytes; a high theoretical capacity of $170 \mathrm{mAhg}^{-1}$; and safety when compared with cobalt oxide-based olivine materials for large-scale applications [1]. However, $\mathrm{LiFePO}_{4}$, when cycled, has a practical capacity much lower than the theoretical capacity. This limitation for commercial applications has mainly been attributed to the low intrinsic electronic conductivity $10^{-11} \mathrm{Scm}^{-1}$ (compared with $10^{-3} \mathrm{Scm}^{-1}$ for $\mathrm{LiCoO}_{2}$ ) and low $\mathrm{Li}^{+}$diffusion coefficient through the $\mathrm{LiFePO}_{4} / \mathrm{FePO}_{4}$ interface [2,3]. To overcome these drawbacks and to improve the electrochemical performance of $\mathrm{LiFePO}_{4}$, many studies have been conducted involving reduction of $\mathrm{LiFePO}_{4}$ particle-size, metal ions doping, carbon coating, use of conductive additives, and synthesis of $\mathrm{LiFePO}_{4}$-porous carbon composites [1,4,5]. Decreasing the $\mathrm{LiFePO}_{4}$ particle size leads to shortening of the $\mathrm{Li}^{+}$diffusion path, but increases the surface area; therefore, the amount of binder needed to glue 
the $\mathrm{LiFePO}_{4}$ particles will increase, leading to a decrease in capacity [6,7]. Metal doping expands the $\mathrm{Li}^{+}$diffusion channel, increasing the output voltage of an $\mathrm{LiFePO}_{4}$-based battery $[8,9]$.

The carbon coating is used to increase the electron migration rate during the battery processes [10-12]. Dispersing conductive additives as metal or carbon black powders with $\mathrm{LiFePO}_{4}$ nanoparticles improve the contact between $\mathrm{LiFePO}_{4}$ and electrolyte, and thus the electronic and ionic conductivity [13-15].

Besides carbon coating or the use of conductive additives, $\mathrm{LiFePO}_{4} /$ porous carbon composites as cathode materials have shown improvements in the lithium storage kinetics [16-19]. With nanostructured $\mathrm{LiFePO}_{4} / \mathrm{C}$ nanocomposites, it is possible to reach extremely high-power densities [20-22]. Ni et al., synthesized carbon-coated $\mathrm{LiFePO}_{4}$-porous carbon as a cathode for a lithium ion battery [23]. Wang et al., prepared a $\mathrm{LiFePO}_{4} / \mathrm{CMK}-3$ composite as a cathode, where CMK-3 is highly conductive carbon with mesoporous channels and interconnected pores networks, prepared by the nanocasting method. $\mathrm{LiFePO}_{4}$ particles are embedded in the mesoporous channels in the carbon matrix. At low current discharge rates, $\mathrm{LiFePO}_{4} / \mathrm{CMK}-3$ delivers a capacity similar to the theoretical one with high capacity retention. At high current rates, the cell also presents satisfactory specific capacity with excellent cyclability [24]. Yu et al., synthesized $\mathrm{LiFePO}_{4} /$ carbon mesoporous nanocomposites by a facile "all in one" hydrothermal method, with excellent capacity retention [25]. Cheng et al., synthesized mesoporous $\mathrm{LiFePO}_{4} / \mathrm{C}$ composites using bimodal mesoporous carbon (BMC). The pore structure of BMC affords good particle connectivity for $\mathrm{LiFePO}_{4}$, and also allows a rigid nano-confinement that controls the particle size. The good performance rate of these electrodes can mainly be attributed to the small particle size and good dispersion of $\mathrm{LiFePO}_{4}$, which improves the ion and electron diffusion [26]. Sun et al., synthesized $\mathrm{LiFePO}_{4}$-carbon mesoporous nanocomposites by a one-pot soft-template method with a high surface area, defined pore size, and homogenous distribution of small particles of $\mathrm{LiFePO}_{4}$. These nanocomposites exhibited a high current rate [27].

The $\mathrm{LiFePO}_{4}$-porous carbon composites, prepared preserving the carbon porosity by mixing of the active $\mathrm{LiFePO}_{4}$ particles with porous carbon particles, could give an improved effect upon cathode performance. In this work, we developed a new method for the synthesis of mesoporous carbon as an additive for $\mathrm{LiFePO}_{4}$. The method is based on the polymerization of resorcinol-formaldehyde in alkaline aqueous medium in the presence of the template system constituted by the triblock copolymer surfactant F108 and tetraethoxysilane (TEOS), following a procedure similar to the one reported using a phenol-formaldehyde resin [28]. The effect of the porous characteristics and graphitic character of the synthesized carbon on the performance of a coin LIB with an $\mathrm{LiFePO}_{4} /$ carbon cathode is studied.

\section{Materials and Methods}

\subsection{Chemicals}

The copolymer triblock surfactant $\mathrm{PEO}_{132} \mathrm{PPO}_{50} \mathrm{PEO}_{132,}$ (F108), $M_{\mathrm{W}}=14600$, resorcinol (99\%), tetraetoxisilane (TEOS, 98\%) and $\mathrm{NaOH}$ were provided by Merck (Darmstadt, Germany). Formaldehyde solution $(37 \%)$ and ultrapure water $\left(18.2 \mathrm{MScm}^{-1}\right)$ were used in all experiments. N-methilpyrrolidone (NMP) and polividen flouride (PVDF) were obtained from Sigma-Aldrich. $\mathrm{LiFePO}_{4}$ (lithium iron (II) phosphate) with bimodal particle size distribution $(0.2-20 \mu \mathrm{m}$, centered at 1 and $6 \mu \mathrm{m})$ was purchased from MTI corporation (Richmond, CA, USA, Reference Powder for Li-ion Battery Cathode, $150 \mathrm{~g} /$ bottle-EQ-Lib-LFPO-S21). Super P carbon (40 nm average particle size), the aluminum foils, coin cell materials, the electrolyte (a mixture of ethylene carbonate and methyl-ethyl carbonate (1:1 in volume) with $1 \mathrm{M} \mathrm{LiFP}_{6}$ ), and the lithium foil were purchased from MTI corporation (Richmond, CA, USA).

\subsection{Synthesis of Mesoporous Carbon (MC)}

F108 was dissolved in $30 \mathrm{~mL} 0.05 \mathrm{M} \mathrm{NaOH}$ solution $\left(\mathrm{H}_{2} \mathrm{O} / \mathrm{F} 108\right.$ molar ratio of 16,900$)$. To this solution, TEOS was added, under stirring, to obtain a TEOS/F108 molar ratio of 50 . The solution 
was kept under magnetic stirring (200-300 rpm) in an oil bath at $45^{\circ} \mathrm{C}$ for $18 \mathrm{~h}$. Then, resorcinol and formaldehyde were added to obtain a solution with a molar ratio of 50TEOS/1surfactant/60 resorcinol/292formaldehyde. The reaction mixture was heated under stirring at $45^{\circ} \mathrm{C}$ for $1 \mathrm{~h}$ and then at $67^{\circ} \mathrm{C}$ for $48 \mathrm{~h}$. The solid was recovered by centrifugation, washed with water, and dried at room temperature overnight. The as-synthesized sample was subjected to pyrolysis at $800{ }^{\circ} \mathrm{C}$ for $3 \mathrm{~h}$ to obtain the composite carbon-silica. The pyrolysis was carried out in a horizontal tubular furnace under an $\mathrm{N}_{2}$ flow rate of $100 \mathrm{~cm}^{3} / \mathrm{min}$ and a heating rate of $2{ }^{\circ} \mathrm{C} / \mathrm{min}$. The composite was treated with $9 \% \mathrm{HF}$ solution over three days to obtain the MC.

\subsection{Preparation of Composites $\mathrm{LiFePO}_{4} / \mathrm{MC}$ and $\mathrm{LiFEPO}_{4} /$ Super $\mathrm{P}$}

For the electrode preparation, $1.5 \mathrm{~mL}$ of NMP and $50 \mathrm{mg}$ of PVDF were mixed and stirred to form a transparent solution. To this solution, $50 \mathrm{mg}$ of carbon (Super P or MC) was added and stirred for one hour, after which $450 \mathrm{mg}$ of $\mathrm{LiFePO}_{4}$ was added and the mixture was stirred for $24 \mathrm{~h}$ in a closed container. Finally, the slurry was spread over an aluminum foil with an automatic coating machine (msk-afa-III, MTI Corporation, Richmond, CA, USA), forming a $10 \mu \mathrm{m}$ thick coating layer. The electrode was dried at $40^{\circ} \mathrm{C}$ for $2 \mathrm{~h}$ and then at $60^{\circ} \mathrm{C}$ for $2 \mathrm{~h}$, and finally left under vacuum for $24 \mathrm{~h}$ at $120^{\circ} \mathrm{C}$, according to procedure previously reported [29]. The dried coated foil was pressed three times using a MSK-HRP 4 hot rolling press at $90^{\circ} \mathrm{C}$ (MTI). The electrodes with $1.8 \mathrm{~cm}$ diameter were cut using an EL-cut (EL-CELL) and kept under humidity- and oxygen-free conditions.

\subsection{Physical and Chemical Characterization of Carbons and Composites}

Nitrogen adsorption/desorption was performed in an ASAP 2020 Micromeritics. The samples were pretreated at $250^{\circ} \mathrm{C}$ over $12 \mathrm{~h}$ under vacuum. The BET model was used to determine the specific surface area and the total pore volume was obtained at $0.99 \mathrm{P} / \mathrm{P}_{\mathrm{o}}$. The mesoporous volume and pore size distribution were obtained using the Barret-Johner-Halendar (BJH) model. The microporous volume was determined by the t-plot method using a non-microporous reference carbon [30].

Small-angle X-ray scattering (SAXS) was performed in the $1<2 \theta<5$ range in a Philips PW1130 equipment using $\mathrm{Cu} \mathrm{K} \alpha$ radiation.

By transmission electron microscopy (TEM, Tecnai G2 F20), the particle morphology and pore features were obtained. The samples were dispersed in ethanol by sonication for $2 \mathrm{~h}$ and then dropped in a copper grid. Structural characterization was carried out by RAMAN (Horiba LabRAM HR, wavelength $532 \mathrm{~nm}$ ) and X-ray diffraction patterns in the $5<2 \theta<70$ range (Philips PW1130), using Cu $\mathrm{K} \alpha$ radiation.

The characterization of the composites was done by XRD (Philips PW1130) in order to confirm the presence of the olivine structure of $\mathrm{LiFePO}_{4}$ and by EDX (SEM, JEOL JSM-6490) to evaluate the carbon and $\mathrm{LiFePO}_{4}$ particles' dispersion.

To determine the decomposition temperature, thermal gravimetric analysis (TGA) of the carbons, under $40 \mathrm{~mL} / \mathrm{min}$ air flow in a temperature range $25-800^{\circ} \mathrm{C}$ with a heating rate of $10^{\circ} \mathrm{C} / \mathrm{min}$, was done in a TGA-Q500 instrument.

\subsection{Electrochemical Characterization of the Composites $\mathrm{LiFePO}_{4} / \mathrm{MC}$ and $\mathrm{LiFePO}_{4} / \mathrm{Super} \mathrm{P}$}

Coin cells were assembled in a glove box under moisture and oxygen levels lower than $0.5 \mathrm{ppm}$. The coin cells were assembled using lithium foil as the anode, the nanocomposite material $\mathrm{LiFePO}_{4} / \mathrm{MC}$ as the cathode, and ethyl carbonate and di-methyl carbonate 1:1 $(v / v) / 1 \mathrm{M} \mathrm{LiPF}_{6}$ as the electrolyte. For comparison purposes, another coin cell was prepared in which the cathodic material was replaced by $\mathrm{LiFePO}_{4} /$ Super $\mathrm{P}$, following the same procedure. Charge/discharge experiments were performed at $0.1 \mathrm{C}$ from $2.5 \mathrm{~V}$ to $4.2 \mathrm{~V}$, where $\mathrm{C}$ is the theoretical capacity of $\mathrm{LiFePO}_{4}\left(170 \mathrm{mAhg}^{-1}\right)$. Additionally, electrochemical impedance spectroscopy (EIS, potentiostat/galvanostat VMP3) was performed on the coin cells before and after the charge/discharge cycles for the nanocomposite electrodes, with $10 \mathrm{mV}$ perturbation applied in the range of frequencies from $1 \mathrm{MHz}$ up to $100 \mathrm{mHz}$ at open circuit conditions. 


\section{Results and Discussion}

\subsection{Porous and Morphological Characteristics of Carbon Samples}

Figure 1a,b present the nitrogen adsorption/desorption isotherms and the BJH pore size distribution of MC and Super P, respectively, and Table 1 presents their porous characteristics. MC exhibits type IV isotherms with $\mathrm{H} 1$ hysteresis loop corresponding to materials with cylindrical mesopores and Super $\mathrm{P}$ exhibits poorer porosity with type II isotherms typical of macroporous materials (Figure 1a).
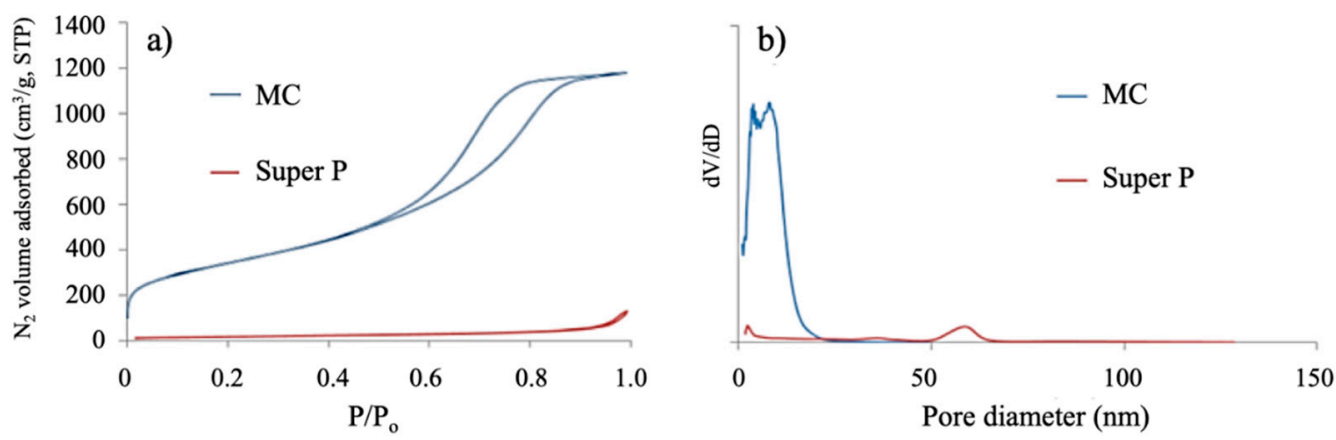

Figure 1. (a) Nitrogen adsorption/desorption isotherms, (b) pore size distributions using Barret-JohnerHalendar (BJH) of the mesoporous carbon (MC) and Super P.

Table 1. Porous characteristics of mesoporous carbon (MC) and Super P.

\begin{tabular}{cccccc}
\hline Carbon & $\mathbf{V}_{\mathbf{p}}\left(\mathbf{c m}^{\mathbf{3}} / \mathbf{g}\right)$ & $\mathbf{S}_{\text {BET }}\left(\mathbf{m}^{\mathbf{2}} / \mathbf{g}\right)$ & $\mathbf{D}_{\text {pore }}(\mathbf{n m})$ & $\mathbf{A}_{\text {micro }}\left(\mathbf{m}^{\mathbf{2}} / \mathbf{g}\right)$ & $\mathbf{V}_{\text {micro }}\left(\mathbf{c m}^{\mathbf{3}} / \mathbf{g}\right)$ \\
\hline MC & 1.82 & 1198 & $3.9 ; 8.2$ & 75 & 0.03 \\
Super P & 0.21 & 57 & $2.1 ; 59$ & - & 0.08 \\
\hline
\end{tabular}

$\mathrm{V}_{\mathrm{p}}$ : total pore volume measured at $0.99 \mathrm{P} / \mathrm{P}_{\mathrm{o}} ; \mathrm{S}_{\mathrm{BET}}$ : $\mathrm{BET}$ area; $\mathrm{D}_{\text {pore }}$ : pore diameter; $\mathrm{V}_{\text {micro }}$ : microporous volume; $\mathrm{A}_{\text {micro }}$ : micro area.

As seen in Table 1, MC exhibits a high BET surface area, and high mesoporous volume with pore sizes around 3.9 and $8.2 \mathrm{~nm}$ (Figure $1 \mathrm{~b}$ ). Super P exhibits a smaller BET surface area and pore volume, represented mainly by macroporous volume corresponding to pores around $59 \mathrm{~nm}$ (Figure 1b).

Origin of the Bimodal Porosity of MC

At $67^{\circ} \mathrm{C}$, the resorcinol/formaldehyde polymerization, in the reaction medium for MC synthesis, causes a synergistic effect with siliceous species in the obtaining of a carbon-silica mesoporous composite, forming intercrossing nets of mesoporous silica and mesoporous carbon, according to previous synthesis with phenol as the carbon precursor instead of resorcinol [28]. After pyrolysis of the composite and silica removal, mesoporous carbon nanoparticles with an average size of around $200 \mathrm{~nm}$ and bimodal mesoporosity are obtained. The pores around $8.2 \mathrm{~nm}$ and $3.9 \mathrm{~nm}$ are attributable to F108 micelles covered mainly by silica and mainly by resol species, respectively, during synthesis. The SAXS spectrum for MC failed to show pore organization.

\subsection{Structural Characterization}

In the TEM micrographs (Figure 2), the carbon MC looks composed of primary spheroidal porous nanoparticles with sizes between 50 and $220 \mathrm{~nm}$, with an average value of $200 \mathrm{~nm}$. According to MTI materials supplier, the graphitic carbon Super $\mathrm{P}$ is composed by nanoparticles with average size of $40 \mathrm{~nm}$. The 3D bimodal porosity of MC nanoparticles (pores around 3.9 and $8.2 \mathrm{~nm}$, measured by $\mathrm{N}_{2}$ adsorption/desorption) is seen in the enlarged TEM image of the surface of one of the particles (upper left inset in Figure 2b). 

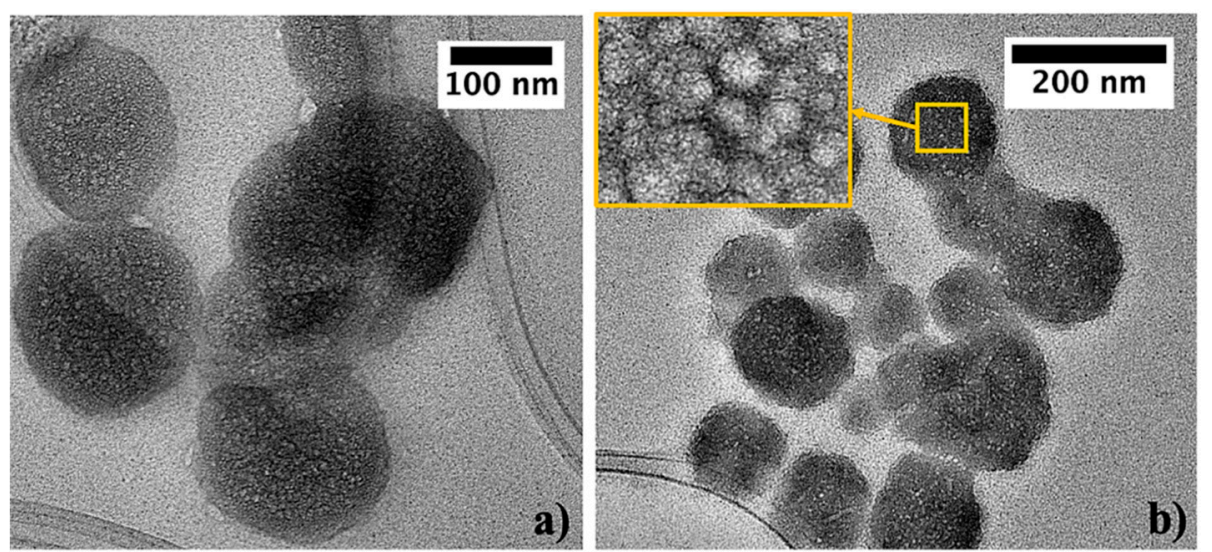

Figure 2. (a) and (b): Transmission electron microscopy (TEM) images of MC material. Upper left inset,

Figure $2 b$ : enlarged image of the surface of a particle.

Figure 3 presents the RAMAN spectra and XRD patterns of MC and Super P. The Raman spectra of MC and Super P, in Figure 3a, show the signals corresponding to the vibrational modes D (A1g) and $\mathrm{G}(\mathrm{E} 2 \mathrm{~g})$, at 1330 and $1596 \mathrm{~cm}^{-1}$, respectively. The $\mathrm{D}$ signal is associated with defects on the graphitic structure and the $G$ signal is associated with graphitic vibrations. The intensity ratio $I_{D} / I_{G}$, in peak areas, defines the amount of defects and thus the degree of graphitization of a carbon, where a higher ratio indicates a higher number of defects. The carbon conductivity depends on its graphitization degree. The $I_{D} / I_{G}$, in peak area ratios, for $M C$ and Super $\mathrm{P}$ are shown in Table 2. The $\mathrm{I}_{\mathrm{D}} / \mathrm{I}_{\mathrm{G}}$ ratio for $\mathrm{MC}$, although lower that than for Super $\mathrm{P}$, can be considered as a value that indicates a good graphitic character.
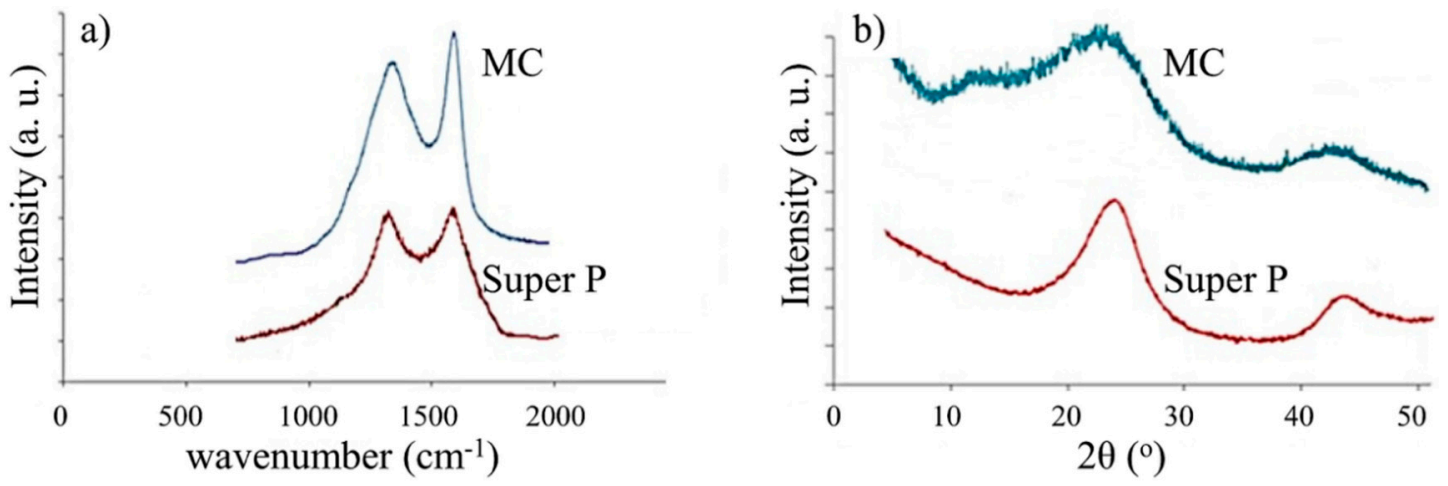

Figure 3. (a) RAMAN spectra and (b) XRD patterns of the MC and Super P.

Table 2. Crystallographic parameters and decomposition temperatures of MC and Super P.

\begin{tabular}{ccccccc}
\hline Carbon & $\boldsymbol{I}_{\boldsymbol{D}} / \boldsymbol{I}_{\boldsymbol{G}}$ & $\boldsymbol{L}_{\boldsymbol{a}}(\mathbf{n m})$ & $\boldsymbol{L}_{\boldsymbol{c}}(\mathbf{n m})$ & $\boldsymbol{d}_{\mathbf{0 0 2}}$ & $\boldsymbol{n}$ & $\boldsymbol{T}_{\boldsymbol{D}}\left({ }^{\circ} \mathbf{C}\right)$ \\
\hline MC & 1.40 & 13.3 & 1.36 & 0.38 & 3.56 & $550-680$ \\
Super P & 0.84 & 22.9 & 8.12 & 0.35 & 23.20 & $650-750$ \\
\hline
\end{tabular}

The XRD patterns of MC and Super P (Figure 3b) show the peaks (002) at $2 \theta \sim 24^{\circ}$ and (100) at $2 \theta \sim 42^{\circ}$ corresponding to graphite. The peak at $2 \theta \sim 16^{\circ}$ for $\mathrm{MC}$ is assigned to aliphatic side chains, attached to the edge of the graphite crystallites [31].

Table 2 presents the crystallographic parameters estimated from Raman data and the XRD patterns, as shown below, and the decomposition temperatures obtained from the TGA analysis.

From the Raman spectrum, the graphitic domain size $L a$ was evaluated using the following equation: $L a(\mathrm{~nm})=\left(2.4 \times 10^{-10}\right) \lambda^{4}\left(I_{D} / I_{G}\right)^{-1}$, with $\lambda=532 \mathrm{~nm}$ [32]. The (002) peak for MC and Super $P$ defines the spacing of aromatic ring layers in their crystallites. The width of this peak, for the two 
carbons, is rather broad, indicating that they exhibit a random layer lattice structure occasioned by defects on the graphitic layers. From the diffraction peak in the plane (002) at $\sim 2 \theta=24^{\circ}$, the graphitic interlayer spacing $d_{002}$, the stacking height $L c$, and the number of graphene stacking layers $n$ were determined. The interlayer spacing $d_{002}$ was calculated from Bragg's Law. $L c$ was determined using the following equation: $L c=0.9 \lambda / \beta_{002} \cos \theta_{002}$, with $\beta_{002}=$ half width of 002 peak in radians and the number of grapheme stacking layers $n$ as $L_{C} / d_{002}$ [33].

Super $\mathrm{P}$ exhibits a higher decomposition temperature and larger graphitic domains, as well as larger $L c$ and $n$ values and a smaller $d_{002}$ than MC (Table 2), which indicates its better graphitic nature. Nevertheless, the moderated graphitic nature exhibited by MC qualifies it as a potential conductive additive.

\subsection{Physical and Chemical Characterization of $\mathrm{LiFePO}_{4} / \mathrm{MC}$ and $\mathrm{LiFePO}_{4} / \mathrm{Super} \mathrm{P}$}

Figure 4 shows the nitrogen adsorption/desorption isotherms and pore size distributions of the prepared electrode materials, and Table 3 shows their porous characteristics.
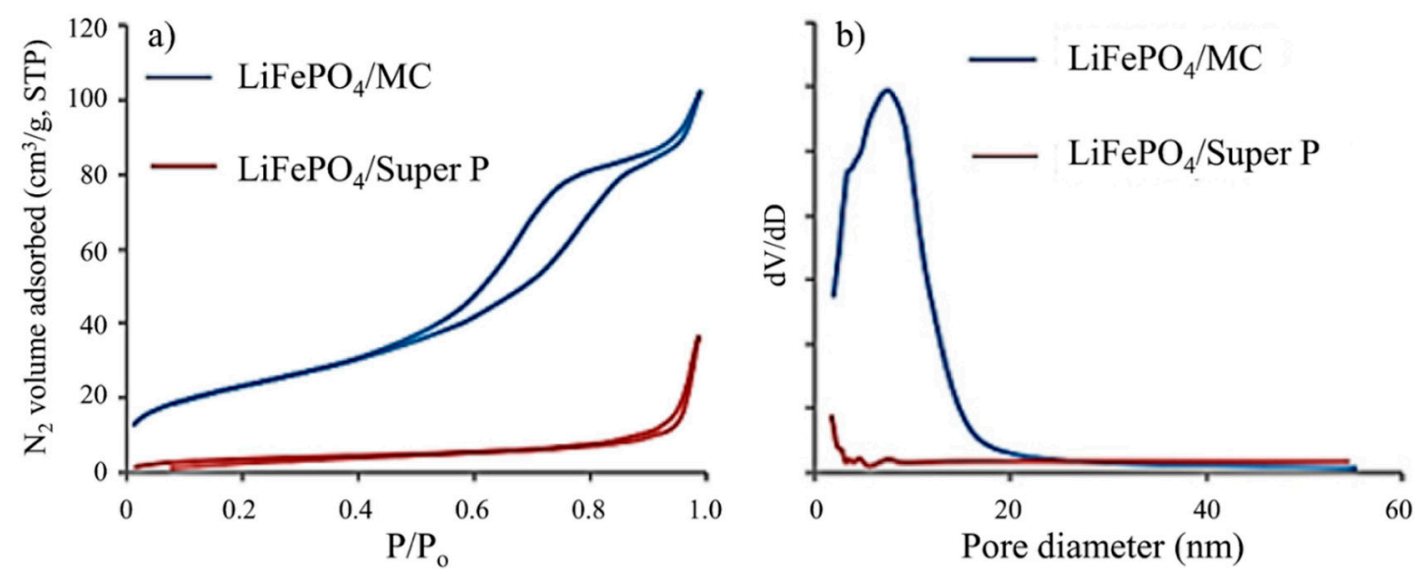

Figure 4. (a) Nitrogen adsorption/desorption isotherms and (b) pore size distributions (BJH) of $\mathrm{LiFePO}_{4} / \mathrm{MC}$ and $\mathrm{LiFePO}_{4} /$ Super P composites.

Table 3. Porous characteristics of the composites.

\begin{tabular}{cccccc}
\hline Sample & $\mathbf{V}_{\mathbf{p}}\left(\mathbf{c m}^{3} / \mathbf{g}\right)$ & $\mathbf{S}_{\text {BET }}\left(\mathbf{m}^{2} / \mathbf{g}\right)$ & $\mathbf{D}_{\text {pore }}(\mathbf{n m})$ & $\mathbf{V}_{\text {micro }}\left(\mathbf{c m}^{3} / \mathbf{g}\right)$ & $\mathbf{V}_{\mathbf{2 - 1 0 ~} \mathbf{n m}}\left(\mathbf{c m}^{3} / \mathbf{g}\right)$ \\
\hline $\mathrm{LiFePO}_{4} / \mathrm{MC}$ & 0.16 & 84 & $3.6,7.7$ & 0.0007 & 0.12 \\
$\mathrm{LiFePO}_{4} /$ Super P & 0.06 & 14 & - & 0.0001 & 0 \\
\hline
\end{tabular}

$\mathrm{V}_{\mathrm{p}}$ : total pore volume measured at $0.99 \mathrm{P} / \mathrm{P}_{\mathrm{O}} ; \mathrm{S}_{\mathrm{BET}}$ : $\mathrm{BET}$ area; $\mathrm{D}_{\text {pore }}$ : pore diameter; $\mathrm{V}_{\text {micro }}$ : microporous volume;

$\mathrm{V}_{2-10 \mathrm{~nm}}$ : volume of the $2-10 \mathrm{~nm}$ pores.

By comparison with the carbons, the composites on average exhibit an increase in macroporous volume resulting from interparticle porosity generated during formation of the composite, but a decrease in mesoporous volume, which is in agreement with the low percent of carbon in the composite. Table 3 shows that $\mathrm{LiFePO}_{4} / \mathrm{MC}$ is the composite with the better mesoporous characteristics (Figure $4 a, b$ ), with a mesoporosity derived mainly by the carbon particles themselves, which is not hindered by the formation of the composite, besides that of the meso-macro porous textural interparticle porosity resulting from the formation of the composite. As a lithium ion battery cathode, $\mathrm{LiFePO}_{4} / \mathrm{MC}$, when compared with $\mathrm{LiFePO}_{4} /$ Super P, thanks to its intraparticle 3D MC porosity, can improve the charge transfer kinetics of the active material with which it is in contact, decreasing the charge transfer resistance and increasing the cell voltage [34]. Li et al., synthetized a mesoporous $\mathrm{LiFePO}_{4} / \mathrm{C}$ nanocomposite, using bimodal mesoporous carbon as continuous conductive networks, which promises high utilization of the active material and offers rapid ion and electron transport. 
A LIB with this composite as the cathode exhibits capacities of $120 \mathrm{mAhg}^{-1}$ and $42 \mathrm{mAhg}^{-1}$ at $0.1 \mathrm{C}$ and $10 \mathrm{C}$ current rates, respectively [26].

The presence of highly crystalline $\mathrm{LiFePO}_{4}$ in the $\mathrm{LiFePO}_{4} / \mathrm{MC}$ composite is confirmed by comparing its XRD pattern with that of the standard $\mathrm{LiFePO}_{4}$ from MTI (Figure 5).

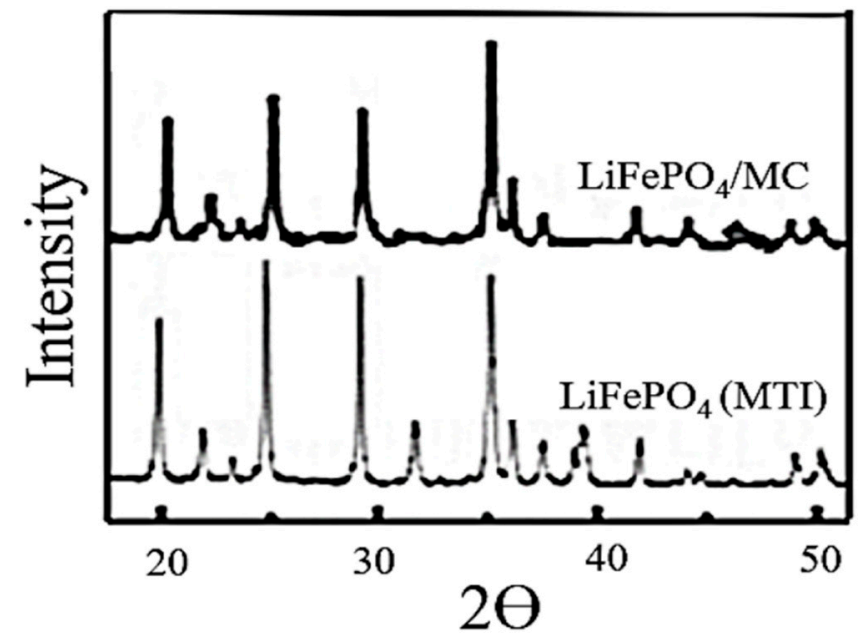

Figure 5. XRD patterns of $\mathrm{LiFePO}_{4} / \mathrm{MC}$ and $\mathrm{LiFePO}_{4}(\mathrm{MTI})$ reported by the MTI corporation.

SEM images of $\mathrm{LiFePO}_{4} / \mathrm{MC}$ and $\mathrm{LiFePO}_{4} /$ Super P composites are presented in Figure $6 \mathrm{a}, \mathrm{b}$, respectively. High dispersion of both carbon and $\mathrm{LiFePO}_{4}$ (white and light grey particles) in the surface of the composites prepared with Super P or MC is observed.
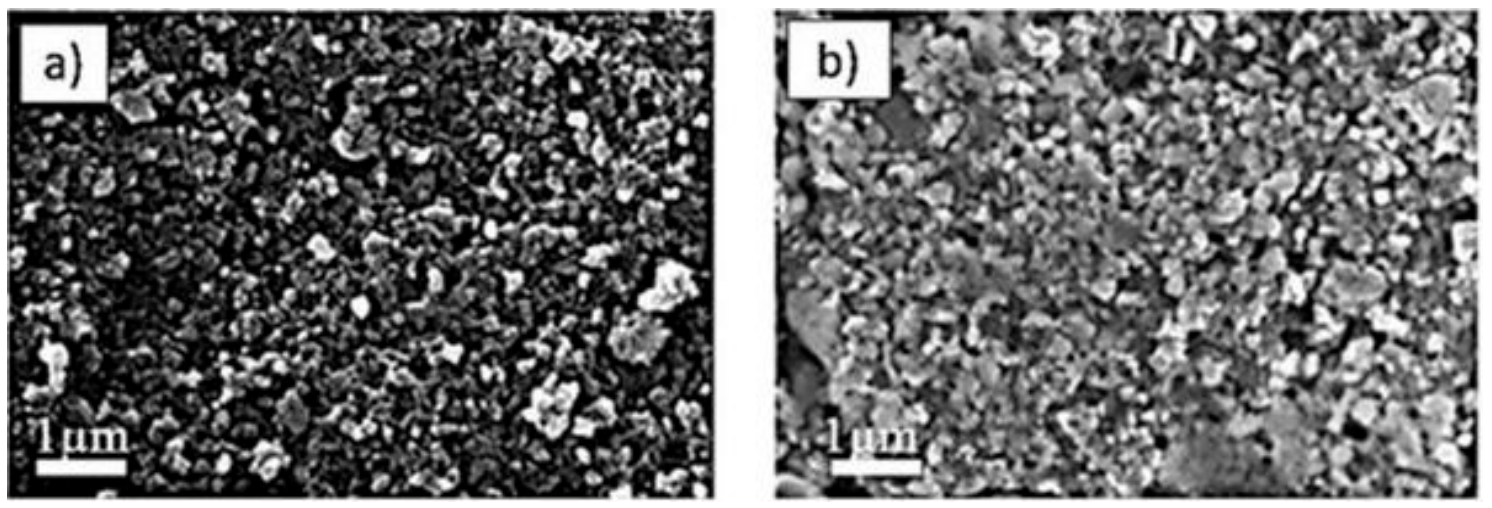

Figure 6. SEM images of (a) $\mathrm{LiFePO}_{4} / \mathrm{MC}$ and (b) $\mathrm{LiFePO}_{4} / \mathrm{Super} \mathrm{P.}$

Figure 7 shows EDX mappings of the composites, where the carbon and $\mathrm{LiFePO}_{4}$ particles in the $\mathrm{LiFePO}_{4} / \mathrm{C}$ composites, along a representative area, show a good dispersion. As can be seen, for $\mathrm{LiFePO}_{4} / \mathrm{MC}$ and $\mathrm{LiFePO}_{4} /$ Super $\mathrm{P}$, the carbon is uniformly distributed across the analyzed area in a relative amount of $41.8 \mathrm{wt} \%$ and $40.2 \mathrm{wt} \%$, respectively, which can include, besides initial carbon particles, binder material involved in the electrode preparation.

The dispersion of conductive carbon in the composites $\mathrm{LiFePO}_{4} / \mathrm{MC}$ and $\mathrm{LiFePO}_{4} /$ Super P predicts the formation of a well interconnected conductive network, developed on particle-particle contact of the $\mathrm{LiFePO}_{4}$ active material, which is the first condition for having good electrochemical performance of a $\mathrm{LiFePO}_{4}$ cathode. The interparticle textural volume for the two composites with the same weight composition is higher for $\mathrm{LiFePO}_{4} / \mathrm{Super} \mathrm{P}$ than for $\mathrm{LiFePO}_{4} / \mathrm{MC}$, because, owing to the porous nature of MC and its larger particle diameter, more volume in the composite is occupied for this carbon than for Super P, and less interparticle volume remains. The larger interparticle volume allows the formation of more straightforward $\mathrm{Li}$ diffusion paths in the case of $\mathrm{LiFePO}_{4} / \mathrm{Super} \mathrm{P}$, and thus better lithium diffusion through the electrode. 

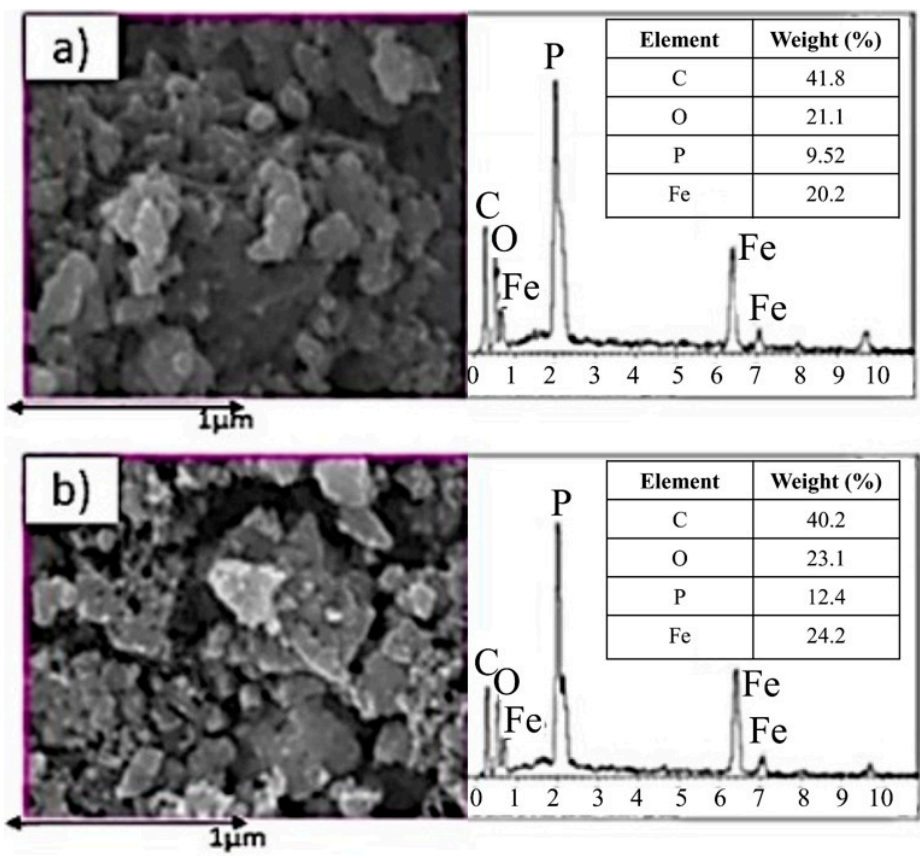

Figure 7. EDX mappings of (a) $\mathrm{LiFePO}_{4} / \mathrm{MC}$ and (b) $\mathrm{LiFePO}_{4} /$ Super P.

\subsection{Electrochemical Performance of Lithium-Ion Battery}

Figure 8 depicts the specific capacity versus voltage curves obtained in the charge/discharge processes at $\mathrm{C} / 10$ current rate, using the nanocomposites $\mathrm{LiFePO}_{4} / \mathrm{MC}$ and $\mathrm{LiFePO}_{4} /$ Super $\mathrm{P}$.
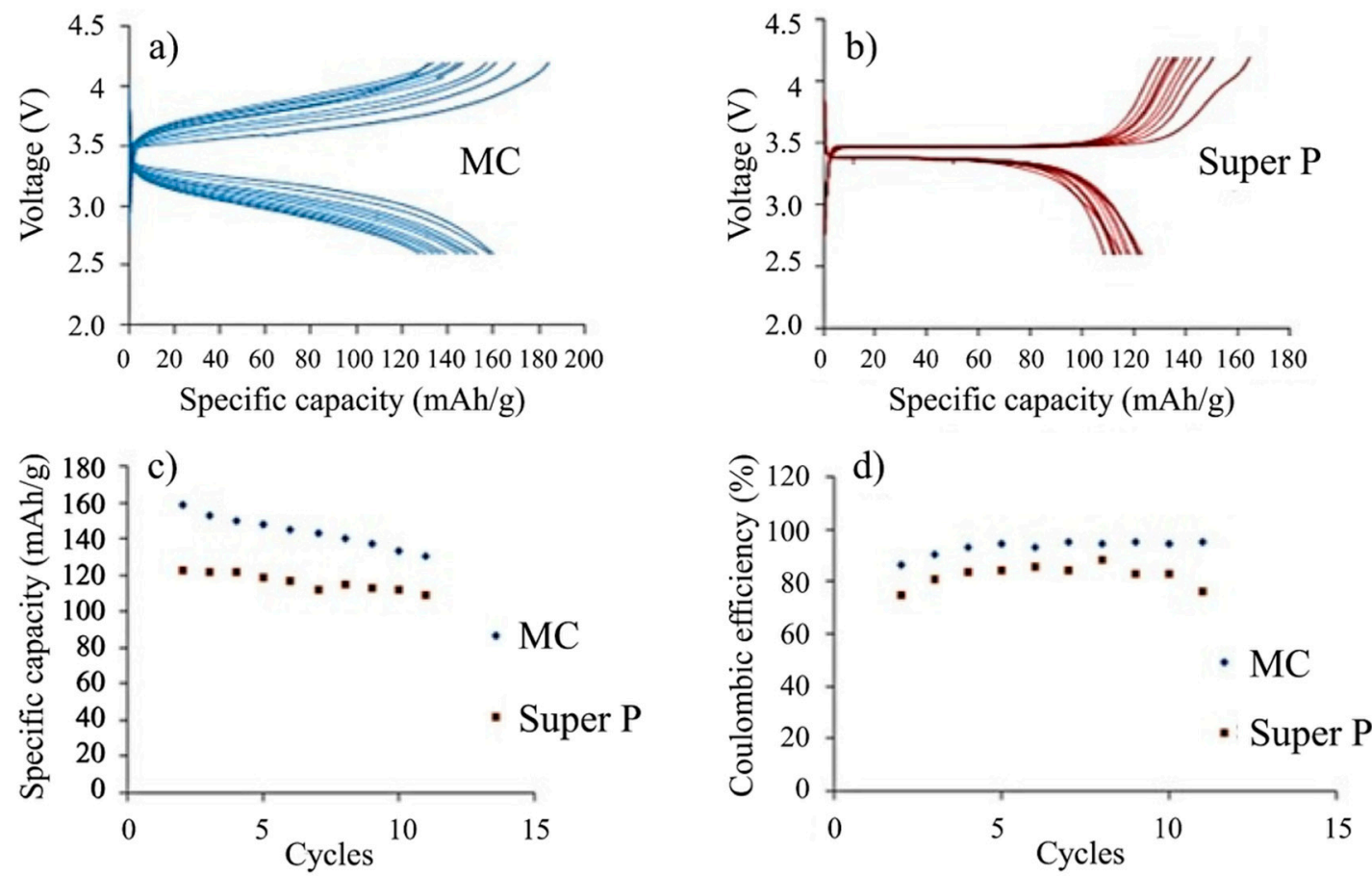

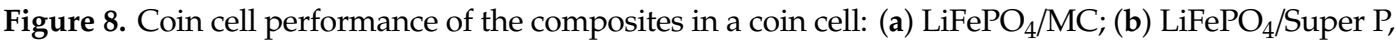
charge/discharge curves at C/10 current rate, during 11 cycles; (c) specific capacity; (d) coulombic efficiency.

$\mathrm{LiFePO}_{4} / \mathrm{MC}$ presents a specific capacity of $161 \mathrm{mAhg}^{-1}$ in the first cycle, which is close to the theoretical capacity of $\mathrm{LiFePO}_{4}\left(170 \mathrm{mAhg}^{-1}\right)$, and maintains $81.1 \%$ of this capacity after 11 cycles at $0.1 \mathrm{C}$ with good coulombic efficiency (Figure $8 \mathrm{a}, \mathrm{c}, \mathrm{d}$ ). After the third cycle, the coulombic efficiency 
in $\mathrm{LiFePO}_{4} / \mathrm{MC}$ increases to the range of $93-96 \%$, and reaches a value above $96 \%$ for the 11 cycle (Figure $8 \mathrm{~d}$ ), demonstrating the outstanding reversibility of the electrode.

$\mathrm{LiFePO}_{4} /$ Super P presents a specific capacity of $126 \mathrm{mAhg}^{-1}$ in the first cycle, which is lower than that of $\mathrm{LiFePO}_{4} / \mathrm{MC}$, and maintains $87.0 \%$ of this capacity after 11 cycles at $0.1 \mathrm{C}$ with lower coulombic efficiency (Figure 8b-d). After the third cycle, the coulombic efficiency in $\mathrm{LiFePO}_{4} /$ Super $\mathrm{P}$ increases to the range of $75-85 \%$, and then decreases to $78 \%$ for the 11 cycle.

The behavior of the composite electrodes can be also analyzed in the Nyquist diagrams obtained by EIS before and after 11 charge/discharge cycles (Figure 9). The semicircle associated with the charge transfer resistance and double layer capacitance, observed at medium frequencies, followed by a straight line at lower frequencies associated to lithium diffusion, shows differences between the two samples [35-37]. The nanocomposite material $\mathrm{LiFePO}_{4} / \mathrm{MC}$ presents lower charge transfer resistance compared with $\mathrm{LiFePO}_{4} /$ Super P before and after the charge/discharge cycles. Although Super $\mathrm{P}$ presents higher conductivity than MC owing to its higher graphitization degree (Figure 3), the specific nature of MC such as the porosity and graphene layer to layer distance affects the charge transfer resistance. The insets in Figure 9 show the relation between the real components of the impedance and the inverse of the square root of the frequency.
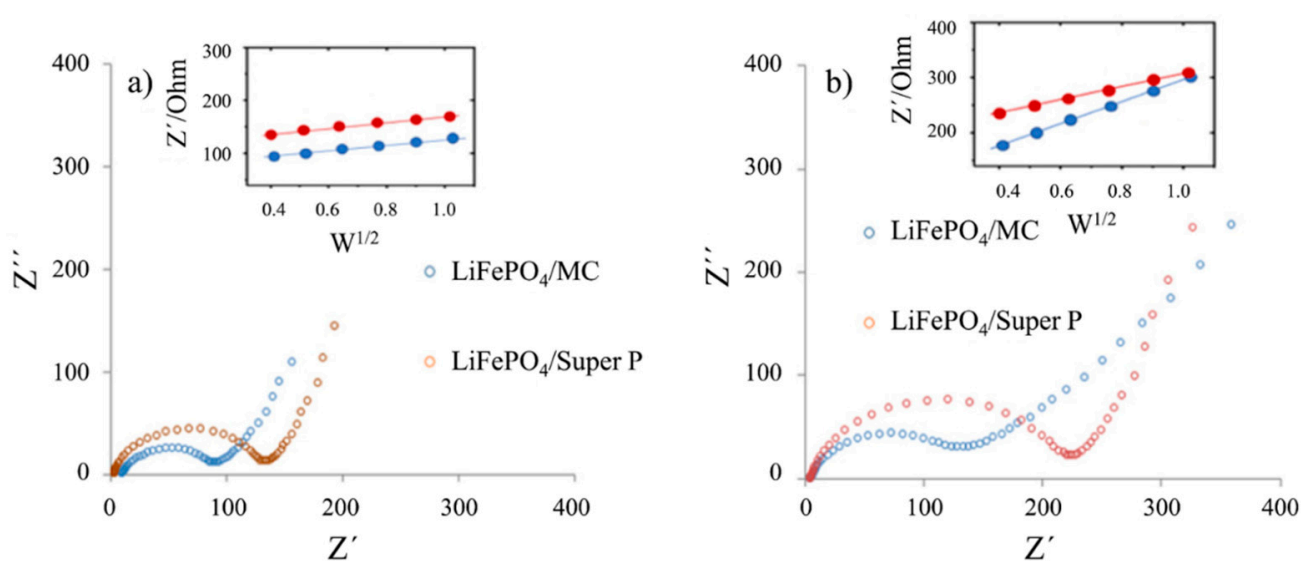

Figure 9. Nyquist diagrams of $\mathrm{LiFePO}_{4} / \mathrm{MC}$ and $\mathrm{LiFePO}_{4} /$ Super $\mathrm{P}$ as cathodes in a coin cell (a) before and (b) after 11 charge/discharge cycles.

The values for the lithium diffusion coefficients $\left(\mathrm{D}_{\mathrm{Li}+}\right)$ in the composites, before and after cycling, are presented in Table 4.

Table 4. Lithium diffusion coefficients in the lithium-ion rechargeable batteries (LIBs) cathodes, obtained from the electrochemical impedance spectroscopy (EIS) characterization.

\begin{tabular}{ccc}
\hline Cathode Material & $\begin{array}{c}\text { Before Cycling, } \\
\boldsymbol{D}_{\mathbf{L i}}{ }^{+}\left(\mathbf{c m}^{\mathbf{2}} \mathbf{s}^{\mathbf{1}}\right)\end{array}$ & $\begin{array}{c}\text { After 11 Cycles, } \\
\boldsymbol{D}_{\mathbf{L i +}}\left(\mathbf{c m}^{\mathbf{2}} \mathbf{s}^{-\mathbf{1}}\right)\end{array}$ \\
\hline $\mathrm{LiFePO}_{4} / \mathrm{MC}$ & $1.7 \times 10^{-10}$ & $1.3 \times 10^{-14}$ \\
$\mathrm{LiFePO}_{4} /$ Super P & $5.3 \times 10^{-10}$ & $8.3 \times 10^{-12}$ \\
\hline
\end{tabular}

Before cycling, $\mathrm{D}_{\mathrm{Li}+}$ for $\mathrm{LiFePO}_{4} / \mathrm{MC}$ is lower than for $\mathrm{LiFePO}_{4} /$ Super P owing to the formation of less interparticle porosity in the case of $\mathrm{LiFePO}_{4} / \mathrm{MC}$, as discussed above. After 11 charge/discharge cycles, the charge transfer resistance for the two composites increased and the lithium diffusion decreased, indicating a decrease in capacity during cycling. This decrease can be attributed to a deterioration of the composites, for instance, by loss of adherence to the PVDF binder; occasioning aggregation of particles; and a decrease in connectivity between $\mathrm{LiFePO}_{4}$ and carbon additives, and thus in retention capacity. The retention capacity can be increased by improving the slurry preparation of the electrode, for instance, by optimizing their composition and the temperature at which the solvent NMP is evaporated. 


\section{Conclusions}

A new bimodal mesoporous carbon (MC) is obtained from pyrolysis at $800{ }^{\circ} \mathrm{C}$ of resol (resorcinol-formaldehyde resin) polymerized at $67^{\circ} \mathrm{C}$, in the presence of tetraethoxysilane (TEOS) and the triblock copolymer Pluronic F108 $\left(\mathrm{PEO}_{132} \mathrm{PPO}_{50} \mathrm{PEO}_{132}\right)$ in alkaline medium with the composition of the following molar ratio: 1F108/60 resorcinol/292 formaldehyde/16,900 $\mathrm{H}_{2} \mathrm{O} / 50 \mathrm{TEOS}$.

MC nanoparticles with an average size around $200 \mathrm{~nm}$, exhibit, by $\mathrm{N}_{2}$ adsorption, non-ordered 3D bimodal mesopores of 3.9 and $8.2 \mathrm{~nm}$ in size and high superficial area $\left(1198 \mathrm{~m}^{2} / \mathrm{g}\right)$ and pore volume $\left(1.8 \mathrm{~cm}^{3} / \mathrm{g}\right)$, and an important graphitic character according to RAMAN and XRD information, which qualifies them as good conductive particles.

The polymerization of resorcinol/formaldehyde at $67^{\circ} \mathrm{C}$, in the $\mathrm{MC}$ synthesis, causes a synergistic effect with siliceous species in the obtaining of mesoporous composites carbon-silica, exhibiting intercrossing nets of mesoporous silica and mesoporous carbon. After silica removal, the carbon shows pores around $8.2 \mathrm{~nm}$ and $3.9 \mathrm{~nm}$ formed by micelles covered mainly by silica species and micelles covered mainly by resol species during synthesis, respectively.

$\mathrm{MC}$ as a conductive additive allows the formation of a composite with well-distributed carbon and $\mathrm{LiFePO}_{4}$ particles, as carbon Super P does. According to the impedance results, the 3D mesoporous contribution of MC improves the charge transfer kinetics considerably compared with Super P, which has a higher graphitic character. On the other hand, the diffusion of lithium ions through the $\mathrm{LiFePO}_{4} / \mathrm{MC}$ cathode, although high, is not better than that obtained through the $\mathrm{LiFePO} /$ Super $\mathrm{P}$ cathode, which indicates that more difficult lithium ion transport occurs in $\mathrm{LiFePO}_{4} / \mathrm{MC}$, owing to the MC larger primary particle size, which brings the formation of longer diffusion lithium paths. The higher efficiency of the $\mathrm{LiFePO}_{4} / \mathrm{MC}$ cathode than $\mathrm{LiFePO}_{4} /$ Super P results from the increase in the charge transfer kinetics owing to the high intraparticle mesoporosity of $\mathrm{MC}$. The lower retention capacity, during cycling, for $\mathrm{LiFePO}_{4} / \mathrm{MC}$ than for $\mathrm{LiFePO}_{4} /$ Super $\mathrm{P}$ can be attributed to a larger decrease in Li diffusion occasioned by a higher loss in interparticle volume owing to the larger MC particle size than Super P. Improving the slurry preparation of the electrode, for instance, optimizing their composition and the temperature at which the NMP solvent is evaporated, should be a focus in order to enhance the MC cathode efficiency for coin LIBs.

Author Contributions: Conceptualization, V.V., B.L., R.P., and L.S.; Formal analysis, V.V., B.L., R.P., and L.S.; Investigation, V.V., B.L., R.P., and L.S.; Methodology, V.V., B.L., and L.S.; Writing-original draft, V.V. and L.S.; Writing一review \& editing, V.V., B.L., R.P., and L.S.

Funding: This research received no external funding.

Acknowledgments: The authors thank the laboratory of electrochemistry of UAM-I (México) for allowing the experimental facilities to make the electrochemical experiments. Victor Velez thanks COLCIENCIAS for the fellowship given by the CONVOCATORIA DOCTORADOS NACIONALES 727.

Conflicts of Interest: The authors declare no conflict of interest.

\section{References}

1. Deng, S.; Wang, H.; Liu, H.; Liu, J.; Yan, H. Research Progress in Improving the Rate Performance of $\mathrm{LiFePO}_{4}$ Cathode Materials. Nano-Micro Lett. 2014, 6, 209-226. [CrossRef]

2. Zhang, Y.; Huo, Q.Y.; Du, P.P.; Wang, L.Z.; Zhang, A.Q.; Song, Y.H.; Lv, Y.; Li, G.Y. Advances in new cathode material $\mathrm{LiFePO}_{4}$ for lithium-ion batteries. Synth. Met. 2012, 162, 1315-1326. [CrossRef]

3. Padhi, A.K.; Nanjundaswamy, K.S.; Goodenough, J.B. Phospho-olivines as Positive-Electrode Materials for Rechargeable Lithium Batteries. Electrochem. Sci. Tech. 1997, 144, 1188-1194. [CrossRef]

4. Wang, Z.-H.; Yuan, L.-X.; Wu, M.; Sun, D.; Huang, Y.-H. Effects of $\mathrm{Na}^{+}$and $\mathrm{Cl}^{-}$co-doping on electrochemical performance in $\mathrm{LiFePO}_{4} / \mathrm{C}$. Electrochim. Acta 2011, 56, 8477-8483. [CrossRef]

5. Lu, Y.; Shi, J.; Guo, Z.; Tong, Q.; Huang, W.; Li, B. Synthesis of $\mathrm{LiFe}_{1-\mathrm{x}} \mathrm{Ni}_{\mathrm{x}} \mathrm{PO}_{4} / \mathrm{C}$ composites and their electrochemical performance. J. Power Sources 2009, 194, 786-793. [CrossRef]

6. Saravanan, K.; Balaya, P.; Reddy, M.V.; Chowdari, B.V.R.; Vittal, J.J. Morphology controlled synthesis of $\mathrm{LiFePO}_{4} / \mathrm{C}$ nanoplates for Li-ion batteries. Energy Environ. Sci. 2010, 3, 457-463. [CrossRef] 
7. Delacourt, C.; Poizot, P.; Levasseur, S.; Masquelier, C. Size Effects on Carbon-Free $\mathrm{LiFePO}_{4}$ Powders. The key to superior energy density. Solid-State Lett. 2006, 9, A352-A355. [CrossRef]

8. Park, K.S.; Son, J.T.; Chung, H.T.; Kim, S.J.; Lee, C.H.; Kang, K.T.; Kim, H.G. Surface modification by silver coating for improving electrochemical properties of $\mathrm{LiFePO}_{4}$. Solid State Commun. 2004, 129, 311-314. [CrossRef]

9. Dominko, R.; Bele, M.; Goupil, J.M.; Gaberscek, M.; Hanzel, D.; Arcon, I.; Jamnik, J. Wired porous cathode materials: A novel concept for synthesis of $\mathrm{LiFePO}_{4}$. Chem. Mater. 2007, 19, 2960-2969. [CrossRef]

10. Wang, Y.G.; Wang, Y.R.; Hosono, E.; Wang, K.X.; Zhou, H.S. The design of a $\mathrm{LiFePO}_{4} / \mathrm{carbon}$ nanocomposite with a core-shell structure and its synthesis by an in situ polymerization restriction method. Angew. Chem. Int. Ed. 2008, 47, 7461-7465. [CrossRef]

11. Huang, H.; Yin, S.C.; Nazar, L.F. Approaching theoretical capacity of $\mathrm{LiFePO}_{4}$ at room temperature at high rates. Electrochem. Solid State Lett. 2001, 4, A170-A172. [CrossRef]

12. Croce, F.; Epifanio, A.D.; Hassoun, J.; Deptula, A.; Olczac, T.; Scrosati, B. A novel concept for the synthesis of an improved $\mathrm{LiFePO}_{4}$ lithium battery cathode. Electrochem. Solid State Lett. 2002, 5, A47-A50. [CrossRef]

13. Doherty, C.M.; Caruso, R.A.; Smarsly, B.M.; Adelhelm, P.; Drummond, C.J. Hierarchically porous monolithic $\mathrm{LiFePO}_{4} /$ carbon composite electrode materials for high power lithium ion batteries. Chem. Mater. 2009, 21, 5300-5306. [CrossRef]

14. Yu, F.; Zhang, J.-J.; Yang, Y.-F.; Song, G.-Z. Up-scalable synthesis, structure and charge storage properties of porous microspheres of $\mathrm{LiFePO}_{4} @ \mathrm{C}$ nanocomposites. Mater. Chem. 2009, 19, 9121-9125. [CrossRef]

15. Oh, S.W.; Myung, S.-T.; Bang, H.J.; Yoon, C.S.; Amine, K.; Sun, Y.K. Nanoporous structured $\mathrm{LiFePO}_{4}$ with spherical microscale particles having high volumetric capacity for lithium batteries. Electrochem. Solid-State Lett. 2009, 12, A181-A185. [CrossRef]

16. Chung, S.Y.; Bloking, J.T.; Chiang, Y.M. Electronically conductive phospho-olivines as lithium storage electrodes. Nat. Mater. 2002, 1, 123-128. [CrossRef]

17. Wang, G.X.; Bewlay, S.; Yao, J.; Ahn, J.H.; Dou, S.X.; Liu, H.K. Characterization of $\mathrm{LiM}_{\mathrm{x}} \mathrm{Fe}_{1-\mathrm{x}} \mathrm{PO}_{4}$ $(\mathrm{M}=\mathrm{Mg}, \mathrm{Zr}, \mathrm{Ti})$ cathode materials prepared by the sol-gel method. Electrochem. Solid State Lett. 2004, 7, A503-A506. [CrossRef]

18. Sarkar, S.; Mitra, S. Carbon coated submicron sized-LiFePO 4 : Improved high rate performance lithium battery cathode. Energy Procedia 2014, 54, 718-724. [CrossRef]

19. Franger, S.; Le Cras, F.; Bourbon, C.; Rouault, H. $\mathrm{LiFePO}_{4}$ synthesis routes for enhanced electrochemical performance. Electrochem. Solid State Lett. 2002, 5, A231-A233. [CrossRef]

20. Liu, J.; Conry, T.E.; Song, X.; Doeff, M.M.; Richardson, T.J. Nanoporous spherical $\mathrm{LiFePO}_{4}$ for high performance cathodes. Energy Environ. Sci. 2011, 4, 885-888. [CrossRef]

21. Konarova, M.; Taniguchi, I. Synthesis of carbon-coated $\mathrm{LiFePO}_{4}$ nanoparticles with high rate performance in lithium secondary batteries. J. Power Sour. 2010, 195, 3661-3667. [CrossRef]

22. Hasegawa, G.; Ishihara, Y.; Kanamori, K.; Miyazaki, K.; Yamada, Y.; Nakanishi, K.; Abe, T. Facile preparation of monolithic $\mathrm{LiFePO}_{4} /$ carbon composites with well-defined macropores for a lithium-ion battery. Chem. Mater. 2011, 23, 5208-5216. [CrossRef]

23. Ni, H.; Liu, J.; Fan, L.-Z. Carbon-coated $\mathrm{LiFePO}_{4}$-porous carbon composites as cathode materials for lithium ion batteries. Nanoscale 2013, 5, 2164-2168. [CrossRef]

24. Wang, G.; Liu, H.; Liu, J.; Qiao, S.; Lu, G.M.; Munroe, P.; Ahn, H. Mesoporous $\mathrm{LiFePO}_{4} / \mathrm{C}$ nanocomposite cathode materials for high power lithium ion batteries with superior performance. Adv. Mater. 2010, 22, 4944-4948. [CrossRef]

25. Yu, L.; Cai, D.; Wang, H.; Titirici, M.-M. Synthesis of microspherical $\mathrm{LiFePO}_{4}$-carbon composites for lithium-ion batteries. Nanomaterials 2013, 3, 443-452. [CrossRef]

26. Cheng, F.; Li, D.; Lu, A.; Li, W. Controllable synthesis of high loading $\mathrm{LiFePO}_{4} / \mathrm{C}$ nanocomposites using bimodal mesoporous carbon as support for high power Li-ion battery cathodes. J. Ener. Chem. 2013, 22, 907-913. [CrossRef]

27. Sun, S.; Ghimbeu, C.M.; Janot, R.; Le Meins, J.-M.; Cassel, A.; Davoisne, C.; Masquelier, C.; Vix-Guterl, C. One-pot synthesis of $\mathrm{LiFePO}_{4}$-carbon mesoporous composites for Li-ion batteries. Microp. Mesop. Mater. 2014, 198, 175-184. [CrossRef]

28. Santa, C.F.; Jaber, M.; Guth, J.L.; Sierra, L. Synthesis of texturally biphasic mesoporous carbon-silica composites and carbons. Microp. Mesop. Mater. 2013, 173, 53-63. [CrossRef] 
29. Guzmán, G.; Vazquez-Arenas, J.; Ramos-Sánchez, G.; Bautista-Ramírez, M.; González, I. Improved performance of $\mathrm{LiFePO}_{4}$ cathode for Li-ion batteries through percolation studies. Electrochem. Acta 2017, 247, 451-459. [CrossRef]

30. Rodriguez-Reinoso, F.; Martín-Martinez, J.M.; Prado-Burguete, C.; McEnaney, B. A standard adsorption isotherm for the characterization of activated carbons. J. Phys. Chem. 1987, 91, 515-516. [CrossRef]

31. Manoj, B.; Kunjomana, A.G. Structural characterization of graphene layers in various Indian coals by $X$-ray Diffraction. IOP Conf. Ser. Mater. Sci. Eng. 2015, 73, 012096-012100. [CrossRef]

32. Cançado, L.G.; Takai, K.; Enoki, T. General equation for the determination of the crystallite size La of nanographite by Raman spectroscopy. Appl. Phys. Lett. 2006, 88, 163106-163108. [CrossRef]

33. Sakintuna, B.; Yürüm, Y.; Çetinkaya, S. Evolution of carbon microstructures during the pyrolysis of Turkish Elbistan lignite in the temperature range $700-1000{ }^{\circ} \mathrm{C}$. Energy Fuels 2004, 18, 883-888. [CrossRef]

34. Liu, H.; Liu, X.; Li, W.; Guo, X.; Wang, Y.; Wang, G.; Zhao, D. Porous carbon composites for next generation rechargeable lithium batteries. Adv. Energy Mater. 2017, 7, 1614-1683. [CrossRef]

35. Schmidt, J.P.; Chrobak, T.; Ender, M.; Illig, J.; Klotz, D.; Ivers-Tiffée, E. Studies on $\mathrm{LiFePO}_{4}$ as cathode material using impedance spectroscopy. J. Power Sour. 2011, 196, 5342-5348. [CrossRef]

36. Illig, J.; Ender, M.; Chrobak, T.; Schmidt, J.P.; Klotz, D.; Ivers-Tiffée, E. Separation of charge transfer and contact resistance in $\mathrm{LiFePO}_{4}$-cathodes by impedance modeling. J. Electrochem. Soc. 2012, 159, A952-A960. [CrossRef]

37. Chen, Y.W.; Chen, J.S. A study of electrochemical performance of $\mathrm{LiFePO}_{4} / \mathrm{C}$ composites doped with $\mathrm{Na}$ and V. Int. J. Electrochem. Sci. 2012, 7, 8128-8139.

(C) 2019 by the authors. Licensee MDPI, Basel, Switzerland. This article is an open access article distributed under the terms and conditions of the Creative Commons Attribution (CC BY) license (http://creativecommons.org/licenses/by/4.0/). 